УДК 111.852

DOI https://doi.org/10.32841/2707-0018.2020.19.10

\author{
Баранова Н. М., \\ кандидат фбілософбських наук, \\ доцент кафедри політології, права та фбілософбї \\ Ніжинського державного університету імені Миколи Гоголя
}

\title{
НАЦІОНАЛЬНО-КУЛЬТУРНА ТРАДИЦІЯ ЯК ЗАСІБ ТРАНСЛЯЦІЇ ЕСТЕТИЧНОГО У СВІТ ЛЮДИНИ
}

\begin{abstract}
Анотація. У статті автор здійснила теоретичне осмислення національно-культурної традиції як засобу входження естетичного в світ людини. Обгрунтувавши засадничі принципи сучасного дослідження проблеми і здійснивши всебічний аналіз, у статті систематизовано досвід вітчизняної та зарубіжної наукової думки, включаючи історичну традицію та сучасний стан естетичної реконструкції національно-культурної традиції. Теоретичний матеріал трансформувався в дослідження особливостей естетичної інтерпретації національно-культурної традиції.
\end{abstract}

Мета дослідження полягає в філософсько-теоретичному аналізі національно-культурної традиції як транслятора естетичного в світ людини.

Методологічна основа дослідження побудована на міждисциплінарному інтегруванні філософських, естетичних, культурологічних, мистецтвознавчих, психологічних та історичних концепцій. Переосмислення класичної теоретичної філософсько-культурної моделі поєднано 3 використанням методології феноменолого-екзистенціалістської традиції, герменевтики, негативної діалектики. У роботі також використано й метод біографічного аналізу, який застосовано для дослідження проблеми крізь призму життя та творчості окремих історичних постатей.

На думку автора, національно-культурна традиція робить естетичне не тільки основою й сутнісним осередком людської культури, але й способом його внутрішньої організації, оскільки певним чином упорядковує духовний світ культури, визначає його «конфігурацію», граничні основи й перспективи, координати та орієнтири, опорні принципи та критерії, інтегрує його в єдине ціле. Тому доцільно говорити про естетичну організацію культури, розуміючи під цим структурованість, системність, інтенціональність її змісту та духовних актів.

Автор вважає, що естетичне являє собою цілісне й усвідомлене переживання співвідношення «людина - світ», духовно-чуттєве «прийняття» світу й людського буття в ньому. Таке осмислене переживання світу, на думку автора, здійснюється в тісній взаємозумовленості та взаємодії глибинного, буттєвого й рефлексивного пластів, оскільки естетичне як стрижневий компонент культури пронизує всю її структуру. Естетичне постає як живе й конкретне емоційно-ціннісне переживання взаємодії людини та світу, духовно-чуттєва причетність до нього в культурі.

Ключові слова: естетичне, естетичний досвід, естетичні почуття, національна культура, традиція.

Постановка проблеми. Подібно до того, як загальний культурницький процес має два спрямування - соціальне та етнонаціональне, - так і етно (національне) культурний процес набуває трьох аспектів: етизації, естетизації та сакралізації.
Потрібно підкреслити: це єдиний процес, у якому виокремити складники можливо лише теоретично.

Етизація, естетизація та сакралізація становлять внутрішній зміст етнонаціонального культурного процесу.

Складний «естетичний спектр» національної дійсності, який містить і основний естетичний тон, і різноманітність естетичних відтінків і переходів, зумовлює національну структуру естетичного ідеалу, конкретний, національний зміст загальних структурних елементів.

Формуючись у системі базових етнокультурних архетипів автохтонного населення регіонів від часів первинного культурного синкретизму, етноестетичні категорії модифікуються під упливом реалій життя, історичної долі народу, розвитку всіх, зокрема й найвищих, елітарних форм духовної культури. Однак як синтезуючий елемент соціальної психології, органічно пов'язаний із базовими рівнями життєдіяльності етносів, їх культури, з усією системою ментальності, естетичне зберігає стабільність, необхідну для забезпечення самоідентичності національних культурних традицій.

Національно-культурна традиція є тією «інтрасуб'єктивною реальністю, що зумовлює органічність розвитку етноестетичних уявлень. Їх семантику складають як індивідуальні, свідомі чинники, так і безособова «культурна аура». Ії̈ інтеріоризація є спонтанним стихійним процесом: смисли потрапляють у сферу підсвідомості особи, закріплюються як нерефлектований досвід, виявляються в подальшій діяльності» $[14$, c. 107$]$.

Аналіз останніх досліджень і публікацій. Теоретичним підгрунтям дослідження стали праці вітчизняних та зарубіжних науковців. Під час вивчення природи та сутності естетичного, окреслення його значення для процесу формотворення культури використано філософську класику, зокрема твори Платона, Аристотеля, Д. Віко, І. Канта, Г.В.Ф. Гегеля, Г. Лейбніца, Т. Адорно, Г. Зіммеля та інших. Естетизмом українського народу захоплювалися Ю. Липа [9], І. Мірчук [12], Г. Ващенко [1; 2], І. Огієнко [13], Ю. Русов [16; 17] та інші. У їх концепціях схильність українців до мистецтва та необхідність зв'язку життя 3 красою вважається ознакою високої духовності. Із домінуванням почуття прекрасного Я. Ярема пов' язує основні риси української ментальності: емоційність, індивідуалізм, неагресивність, допомогу ближньому [20]. На противагу зазначеним дослідникам, Д. Донцов і В. Липинський убачають у естетичній спрямованості народу його нездатність до творчості у сфері політики і, відповідно, певну обмеженість $[3 ; 4 ; 5 ; 10]$. М. Шлемкевич зауважує, що українська емоційність та захоплення красою призвели до втрати 
світоглядними зусиллями необхідних ясності й виразності, що викликало духовну кризу [19]. Дослідники української національної культури (М. Грушевський, І. Крип’якевич, Д. Чижевський) шукали витоки естетизму в міфологічній свідомості.

Мета й завдання дослідження полягає у філософсько-теоретичному аналізі національно-культурної традиції, у дослідженні їі як засобу трансляції естетичного у світ людини, у культуротворчий процес.

Виклад основного матеріалу дослідження. Розглядаючи роль національно-культурної традиції як транслятора естетичних цінностей в світ людини, потрібно підкреслити, що жодне нове покоління не може обійтися без цих надбань культури, знань, традицій, етичних норм та інших цінностей, які сформовані до нього та укорінюються в його свідомості, уходять у плоть і кров його, як кажуть, разом із молоком матері, i тому стають для нього чимось невіддільно близьким, рідним. Таким чином, нове покоління будує свій національно-духовний будинок на фундаменті, який заклали його пращури.

«Історія культури є не тільки історією змін, але й історією збирання цінностей, які залишаються живими і дійовими елементами культури у наступному розвитку» [11, с. 5].

I культура вже не є лише об'єктом, який потрібно збирати, використовувати, споживати, - вона «розчиняється» в «силовому полі» стосунків особистостей, вона не просто пізнається, а переживається в почуттях, наповнює та перетворює їх.

Естетичне займає важливе місце в процесі формотворення культури. Його можна розглядати 3 погляду становлення в культурно-історичному контексті як особливого духовного феномена або як таку категорію, що вже сформувалася та функціонує в реальному суспільно-культурному середовищі. Необхідно зауважити, що естетичне як атрибут культури функціонує не у своєму «чистому» вигляді, а в конкретних формах, тобто як прекрасне, піднесене, трагічне, комічне тощо. У зв'язку з цим виникає потреба розглядати місце й роль кожної із цих категорій у процесі практичного й художнього освоєння світу, аналізувати їх розвиток і збагачення в процесі культуротворення. Якщо конкретизувати, то нас цікавить практична функція естетичного як специфічної детермінанти творчої діяльності.

Естетичне $€$ необхідним компонентом активно-творчого відображення дійсності будь-якою формою суспільної свідомості.

Маючи безпосереднє відношення до культуротворчої діяльності людини, естетичне являє собою досить рухому динамічну систему, яка у своїй змінюваності постійно утримує константу, що визначається. Іншими словами, це $є$ процес духовного, ідеального цілепокладання, яке можливе лише як акт суспільної діяльності.

Естетичне, відображаючи об'єктивну дійсність, яка завжди постає через конкретно-історичні способи й форми діяльності суб'єкта, містить у собі певний зріз практичних форм освоєння людиною світу, віддзеркалює в собі певний рівень культури. Будучи активно-творчим відображенням дійсності, естетичне втілює в собі як об'єктивність, так і суб'єктивність, що є діалектичними моментами його форми існування.

Здатність естетичного передавати різноманітні можливості й модальності художнього вираження характеризує його загальноуніверсальну значущість, що реалізується через художні форми у сфері суспільного буття та свідомості людини. «Потреба людини в образі вищої, ідеальної доскона- лості й краси повною мірою відповідає її природі як істоти не просто споглядальної, а діяльної, активно-творчої» [6, с. 104].

Національно-культурна традиція як засіб взаємодії $з$ дійсністю, як естетичний досвід людства, розкриває особливу - «поетичну» - правду про світ і про місце людини в ньому. Якщо для мислячої людини, що теоретично пізнає світ, важливою є сукупність абсолютно нейтральних стосовно неї об'єктивних фактів, які повністю очищені від усіляких слідів людської конкретно-чуттєвої присутності в цьому світі (якими є світи математичних, фізичних та інших об'єктів), то світ суб'єкта, що естетично сприймає навколишнє,- одухотворений, наповнений людським змістом.

Національно-культурна традиція через естетичний досвід розкриває такий аспект взаємовідношення людини й світу, такі його сторони, які не властиві ніяким іншим видам людського досвіду, не виявляються ніяким іншим способом духовного освоєння світу, і тому потрібно стверджувати науковість дослідження не тільки на теоретично-раціональному методі усвідомлення світу, а й використовувати дані естетичного досвіду. «Виробляючи свої поняття про Світ, Людину й Культуру, ми повинні узгоджуватися з поетичною, ліричною правдою про них, бо цінності, які розкриваються й творяться мистецькою традицією як естетичною діяльністю, є не проекція на світ суб'єктивних потреб, а вираження реального й у цьому смислі об' єктивно існуючого взаємовідношення людини й світу» [18, с. 47].

Н. Чавчавадзе у праці «Культура й цінності» вважає естетичне особливим видом освоєння дійсності, своєрідною формою усвідомлення індивідом світу й себе, специфічною формою досвіду, яка відрізняється від досвіду пізнавального, морального й релігійного. Особливість естетичного досвіду полягає в його спрямованості на естетичні цінності - на їх сприйняття, тобто переживання, в одному випадку, і на їх творення, творчість, в іншому.

Таким чином, Н. Чавчавадзе для того, щоб визначити місце, роль та значення естетичного в культурі, проводить аналогію між культурою та мистецтвом як однієї з форм культури. Така аналогія цілком виправдана, оскільки й культура, й частково мистецтво - це процеси творчої діяльності людини.

Мистецтво $з$ його специфічною якістю художності становить вищу форму естетичного. Уміння бачити й оцінювати прекрасне, піднесене, трагічне, комічне, граціозне тощо у їх неповторно-індивідуальних проявах потребує наявності високорозвиненого смаку, високої культури бачення та переживання. А вміння визначати й оцінювати естетичні цінності - це теж свого роду мистецтво. Але мистецтво, яке виражається та втілюється в художній творчості, передбачає не тільки здатність цього мистецтва вирізняти й цінувати прекрасне, трагічне, комічне тощо, не тільки вміння бачити естетичну цінність там, де їі донині пір ніхто не бачив, але й здатність створювати нові, естетичні цінності. Оскільки в мистецтві сутність естетичного досвіду розкривається повністю, то воно й визначається як вища, найбільш розвинена форма естетичного в світі людини.

У сутності мистецтва найбільш яскраво виражений і характер естетичної цінності. Оскільки: 1) мистецтво є художньо-образним вираженням людського буття, зображенням, що сприймається чуттєво, і виявленням сенсу й особливостей цього буття; 2) специфіка мистецтва, його відмінність від інших форм усвідомлення людиною себе та свого світу полягає 
в цій образотворчо-виразній виявленості надчуттєвого (духовного, ідеального тощо) змісту, у прояві надчуттєвого в чуттєвому. У цьому ж також полягає специфіка естетичної цінності у прояві душевно-духовно-ідеального змісту в чуттєвій «плоті» естетичного предмета.

Іншими словами, естетична цінність і $є$ саме цінністю втілення, пронизування «тіла» естетичного об'єкта світлом його «душі», є цінністю еманації внутрішнього в зовнішньому, змісту у формі, сенсу в символі тощо. Таким чином, це цінність виявлення - вираження, розкриття внутрішнього в зовнішньому, надчуттєвого в чуттєвому, значення в знакові й так далі.

Саме через те, що естетична цінність є виявом, виразним розкриттям, вона за внутрішньою суттю відкрита для всіх інших цінностей і передусім для цінності істини й добра. Тому мистецтво, специфічну цінність якого потрібно вбачати в художності, естетичності, може бути носієм майже всіх відомих цінностей - утилітарних, особистісних, соціальних, політичних, правових, релігійних тощо.

Крім того, через певну прозорість і відкритість естетичної цінності для всіх інших цінностей і взагалі для будь-якого душевно-духовно-ідеального змісту, через те, що мистецтво може відобразити практично всі сфери дійсності, воно виражає особливу, так звану художню (у нашому розумінні), естетичну правду про цю дійсність - правду, яка в певних суттєвих аспектах не тільки не поступається цінності наукових істин, але, мабуть, і перевершує їх. Напевно, тому естетичний досвід має світоглядне значення, світоглядну цінність, і дані цього досвіду повинні бути враховані у філософському світогляді поряд із даними наукового й морального досвіду.

За своєю суттю культура становить єдність ідеального і реального, суб'єктивного і об' єктивного, необхідного i сущого, духовного і матеріального. Спираючись на зазначене вище, майже теж саме можна й потрібно стверджувати про мистецтво, бо саме воно є реалізацією ідеального, об'єктивацією суб'єктивного, матеріалізацією духовного, здійсненням належного, тобто втілення сущого в те, чим воно повинно бути.

Величезну роль національно-культурної традиції в презентації естетичного, у виявленні гармонізації в прекрасних і доцільних формах, які створюються людиною, потрібно використовувати в розв'язанні сучасних проблем культуротворення. Тут - широке коло застосування саме естетичних критеріїв того, як можна впливати на негативні явища в суспільстві чи, принаймні, запобігати їм.

«Естетичне у своїй духовності не залежить від вузького раціоналізму, практицизму, однак не можна заперечувати й те, що естетичне в повсякденному житті людини разом із різного роду моральними установками залишається незмінною «охоронною грамотою» стосовно збереження цінностей природи й культури як найвищих реліктів» $[8$, с. 11].

Естетизм національно-культурної традиції породжений самою реальністю, його функціональне значення на сучасному етапі невпинно зростає, сфера впливу поширюється неймовірними темпами. Він завжди присутній в суспільних процесах, що відбуваються, в історичних подіях у динамізмі людського духу, в утвердженні таких вічних цінностей, як істина, добро, краса. Естетичне акумулює грані цих цінностей.

Людина знаходиться в середовищі національно-культурної традиції, яке спеціально організоване, проникнуте естетичною атмосферою. Годі й шукати більш кращої форми та способу прояву естетичного, які демонструє національно-культурна традиція в сучасній культурі. Відомі теоретики сьогодення поки що не відмовилися від думки про те, що національно-культурна традиція створює для людини цілісне, естетично й художньо значуще предметне середовище. Їх ідеал - це таке проникнення естетичного в життя та діяльність людини, коли те й інше стають творчими, приносять задоволення та дарують насолоду, підносять людину на більш високий щабель свого розвитку.

Процес творення культури - це певна часова послідовність, яка під час естетичного переживання визначає смисложиттєву цінність минулого, сучасного та майбутнього. Естетично освоєний період переосмислюється щоразу з урахуванням чинних традицій, які перебувають у взаємоспрямованому русі двох протилежних метаморфоз - форми діяльності та форми речі в їх суперечливому взаємотворенні.

У той же час культура в процесі узагальнення усталених традицій суспільства й індивідуального досвіду формується відповідно до цілеспрямованості історичного процесу.

Зміна часових періодів у розвитку культури передбачає «бачення реальності з якоїсь певної точки» [15, с. 78$]$.

Культура минулого виявляється згорнутою в часовий цикл, рух якого цілеспрямований від початку до початку. Знання першоначал керує самопізнанням.

Сучасна культура досліджується як нескінченний розгорнутий ланцюг прямих проекцій вічності. Споглядання розуміється як процес залучення до творчості Абсолюту: «Усе, що існує - витвір абсолютної краси, сформований за подібністю до неї, і це формування здійснюється на основі залучення» [7, c. 120].

Висновки. Отже, на якій би стадії розвитку не знаходилася певна культура, у неї завжди є своя національна, самобутня традиція. Досліджуючи культуру минулого, учені примусили «заговорити» письмена народів майя та кам'яні ідоли острова Пасхи, наскельні зображення Франції, північної Скандинавії, Каліфорнії тощо. I вони переконливо доводять, що естетичне було постійним супутником людини в різні періоди іiі життя.

\section{Jimepamypa:}

1. Ващенко Г. Виховання волі і характеру. Ч. І: Психологія волі і характеру. Лондон : Вид. Спілки укр. молоді, 1952. 257 с.

2. Ващенко Г. Твори. Київ : Школяр «Фада» ЛТД, 2000. Т. 5 : Хвороби в галузі національної пам'яті. 2003. 335 с.

3. Донцов Д. Де шукати наших історичних традицій. 2-е вид. / Донцов Д. Львів : Укр. вид-во, 1941. 112 с.

4. Донцов Д. Дух нашої давнини. 2-е вид. Дрогобич : Відродження, $1991.341 \mathrm{c}$.

5. Донцов Д. Націоналізм. 3-те вид. Лондон : Укр. вид. спілка. Торонто : Ліга визволення України, 1966. 363 с.

6. Крутоус В.П. Категория прекрасного и эстетический ідеал. Москва : Изд-во Моск. ун-та, 1985. 166 с.

7. Кузанский Николай. «Вся ты прекрасна, возлюбленная моя». Эстетика Ренессанса (антология): В 2 т. Москва : Искусство, 1981. T. 2. C. $115-143$.

8. Кучерюк Д.Ю. Естетичне сприйняття предметного середовища. Київ : Наук. думка, 1973. 143 с.

9. Липа Ю. Призначення України. 2-е вид. Львів : Просвіта, $1992.270 \mathrm{c}$

10. Липинський В. Листи до братів-хліборобів про ідею і організацію українського монархізму: Пис. 1919-1920 р.р. Укр. суспільно-політична думка в XX ст.: Документи і матеріали. Мюнхен : Сучасність, 1983. Т. 1. С. 483-506. 
11. Лихачев Д.С. Развитие русской литературы X-XVII веков. Эпохи и стили. Ленинград : Наука, 1973. 254 с.

12. Мірчук I. Історія української культури. Мюнхен. Львів, 1994. $286 \mathrm{c}$.

13. Огієнко І. Українська культура. Коротка історія культурного життя українського народу. Київ : Фірма «Довіра», 1992. 141 с.

14. Орлова T.I. Естетика синтезу: категорії, універсалії, парадигми (В контексті художньої творчості). Київ : Абрис, 2002. 159 с.

15. Парахонский В.А. Язык культуры и генезис знания. Київ : Наук. думка, $1988.210 \mathrm{c}$.

16. Русов Ю. Душа народу і дух нації. Філадельфія : Америка, 1948. $153 \mathrm{c}$.

17. Русов Ю. Той, хто «багато знав того, що ми давно забули». Лондон : Вид. УВС, 1954. 19 с

18. Чавчавадзе Н.З. Культура и ценности. Тбилиси : Мецниереба, 1984. $171 \mathrm{c}$.

19. Шлемкевич М. Загублена українська людина. Київ : МП «Фенікс», 1992. $168 \mathrm{c}$.

20. Ярема Я. Над Сяном. Листопадові дні 1918 р. в Перемишлі: Події і роздуми. Львів, 1997. 96 с.

Baranova N. National and cultural tradition as means of transmitting the aesthetic into the human world

Summary. The immediate existence of the consciousness of nations, the form of life of ethnic groups, presents an aesthetic world experience, which is accumulated in the national-cultural tradition as a specific form of reflection of reality. The phenomenon of national-cultural tradition can be detected and comprehended by studying the conditions on the basis of which the aesthetic process arises as a necessary and important attribute of culture.

The purpose of the study is philosophical and theoretical analysis of the aesthetic principles of national cultural traditions in the representation of its identity as an aesthetic phenomenon.

The methodological basis of the study is based on the interdisciplinary integration of philosophical, aesthetic, cultural, artistic, psychological and historical concepts. Reinterpretation of the classical theoretical philosophical and cultural model is combined with the use of the methodology of the phenomenological-existentialist tradition, hermeneutics, and negative dialectics. The method biographical analysis is also used in the work, which is applied to study the problem through the prism of life and creativity of individual historical figures.

The main results lie in the fact that the reflection of the national-cultural tradition as an aesthetic phenomenon was performed in the work for the first time, as well as the interpretation of "national-cultural tradition" as a philosophical and theoretical concept was made. In the work, the cultural tradition and its role and place in national life are considered exclusively in connection with the analysis of aesthetic problems and in those aspects that influence the character of the sensory culture of a man.

The theoretical and practical significance of the study is to expand the theoretical plane of aesthetics and other sciences in terms of comprehension, and in certain problems, rethinking the aesthetic existence of the national-cultural tradition.

Conclusions and provisions of the research can be used in search of new spiritual values, in the development of the concepts of interethnic dialogue, in the development of value orientations in the process of state-building and the creation of socio-cultural models.

In the article the theoretical judgment of national-cultural tradition as aesthetic phenomenon is carried out. Having proved basic principles of modern research of a problem and, having carried out the all-round analysis of concepts culture, national, tradition, aesthetic, a ceremony, the article reveals manysided nature of display and constructive ability of aesthetic in comprehension-cultural tradition's existence.

For the first time in the Ukrainian aesthetics experience of domestic and foreign scientific idea, including historical tradition and a modern condition of aesthetic reconstruction of such phenomenon as national-cultural tradition is systematized. The theoretical material was transformed to research of features of aesthetic interpretation of nationalcultural tradition, on particular aesthetics of traditions of the Ukrainian culture and practice of functioning of a ritual component in aesthetic structure of national-cultural tradition.

Key words: aesthetic, aesthetic experience, aesthetic feelings, national culture, tradition. 